Int. J. Electrochem. Sci., 14 (2019) 10870 - 10887

\title{
Corrosion Behaviour of 2205 Duplex Stainless Steel in Oilfield Production Fluid Containing Sulphate-reducing Bacteria
}

\author{
Xu Chen, Anqi Gong, Jiaxing Yang, Hongjin Li, Wuqi Song, Chuan He* \\ School of Petroleum Engineering, Liaoning Shihua University, Fushun 113001, China \\ *E-mail: hechuan024@ sina.com
}

doi: $10.20964 / 2019.12 .62$

Received: 11 July 2019 / Accepted: 23 September 2019 / Published: 29 October 2019

\begin{abstract}
The corrosion behaviour of 2205 duplex stainless steel (DSS) in sulphate reducing-bacteria (SRB)-free and SRB-containing oil-field production fluid are performed via electrochemical techniques, microscopic imaging, and X-ray photoelectron spectroscopy (XPS). The results show that the corrosion morphology of 2205 DSS in oil field production fluid is pitting corrosion, and the pit becomes deeper in case of bacteria. The corrosion mechanism of 2205 DSS varies depending on the SRB growth stage. Corrosion is inhibited in the steady growth stage, but it is greatly accelerated during the other stages. Observed results of XPS demonstrate that the passivation film obtained in the presence of SRB comprises sulphides of $\mathrm{Cr}$ and $\mathrm{Fe}$. The sulphide-containing passivation film is more easily penetrable by aggressive anion and the local corrosion is accelerated compared to the sulphidefree passivation film.
\end{abstract}

Keywords: 2205 Duplex stainless steel; sulphate reducing-bacteria; growth stage; microbiological corrosion; vulcanization

\section{$\underline{\text { FULL TEXT }}$}

(C) 2019 The Authors. Published by ESG (www.electrochemsci.org). This article is an open access article distributed under the terms and conditions of the Creative Commons Attribution license (http://creativecommons.org/licenses/by/4.0/). 